Oskar Szwabowski (iD http:/orcid.org/0000-0002-7464-0081

Uniwersytet Szczeciński

\title{
We władzy słów i spojrzenia. Bartleby, impotencja władzy i nawiedzony uniwersytet
}

\author{
Abstract \\ In the power of words and gaze. \\ Bartleby, the impotence of power and the haunted university
}

In the article I analyze the question of power in the novel written by Bartleby. First I ask about Bartleby's mechanism of subsumption under capitalism society. Two main strategies of power - in order to be seen and to be spoken - are analyzed using the concept of poststructuralism theory. I show that Bartleby is not something that can be satisfied. Bartleby is a boundary of power(s) and the escape route. Second I ask how Bartleby can change our thinking and practice in higher education.

Key words: Bartleby, study, higher education, power, resistance

Słowa kluczowe: Bartleby, studiowanie, edukacja wyższa, władza, opór

\section{Notatka z ćwiczeń}

$\mathrm{Na}$ ćwiczeniach z filozofii edukacji proszę studentki i studentów, aby napisali krótką charakterystykę idealnego studenta. Zaznaczam od razu, że nie będą później siebie z tym, co napisali, porównywali, ani innych podobnych poniżających praktyk nie będzie. Najlepiej w punktach proszę zapisać, mówię, krótko, dwie, trzy minuty na przygotowanie. Rok za rokiem, grupa za grupą, schematyczne wprowadzenie do zajęć poświęconych Bartleby’emu. I równie typowe 
odpowiedzi. Poza drobnymi, nieistotnymi szczegółami, obraz wyłania się taki sam: pracowity, punktualny, zawsze przygotowany, aktywny, kulturalny, robi notatki, ma je i pożycza, jest oczytany, pomocny i tak dalej - miły, posłuszny, wykonuje polecenia, czyta, co ma zadane. Zjawa z mokrych snów nauczycieli.

Zostawmy to na razie i przejdźmy do czegoś innego. Rozdaję wybrany fragment opowiadania Hermana Melville'a pod tytułem Kopista Bartleby. Historia $z$ Wall Street. Na początku jest to praca w grupach dotycząca samego czytania tekstu, możliwych strategii radzenia sobie $\mathrm{z}$ materiałem. Pod koniec proszę o charakterystykę osobliwego kopisty. Mniej więcej rok za rokiem, grupa za grupą, obraz powstaje podobny: ma problemy psychiczne, wycofany, pogrążony w depresji, „woli nie”, tajemniczy, nie chce pracować, blady, chory - coś niezdrowego, dziwnego, trudnego do dopasowania, w ogóle do ujęcia.

Ok, luz, mówię, to teraz, zobaczmy, niektórzy mówią, że Bartleby jest idealnym studentem. O co chodzi? Jak to rozumieć? I nie, to nie żarty, to całkiem na serio. I idealny nie oznacza uogólnienia opisu istniejących studentów, ale ma dość potoczne znaczenie, $w$ stylu idealnego męża. To jest postulat: studenci powinni być jak Bartleby?

Że co? Że jak to? To jakieś głupie jest...

Wróćmy do tekstu. Przeczytajmy go jeszcze raz. Bo może rzeczywiście to jest głupie, może rzeczywiście jest to jakaś filozoficzna ściema.

I wróćmy jeszcze raz.

I jeszcze raz.

\section{Widma, z którymi nadchodzisz}

I jeszcze raz. Powroty do tekstu kierowane były etycznym podejściem do czytania (zob. Burzyńska, 2013), starającym się nie narzucać własnych idei tekstowi ani nie wykorzystywać go jak mi się podoba, ale próbującym zrozumieć tekst-Innego na tyle, na ile to możliwe. Otworzyć się na spotkanie. Na spotkania, na wielość. Tekst, jak i sam Bartleby, rozszczepia się, staje się widmem.

Widmo jest zawsze mnogie. Widmo jest czymś, co jest trudne do ujęcia „widmo jest paradoksalnym wcieleniem, stawaniem-się-ciałem, pewną zjawiskową i cielesną formą ducha. Staje się on pewną 'rzeczą', którą trudno nazwać: ani duszą, ani ciałem, a zarazem i jedną, i drugim” (Derrida, 2016, s. 24). Ani martwy, ani żywy, rzuca wyzwanie. Wielość widm, wielość wyzwań, linii rozchodzenia się światła. I rozmazany obraz czegoś, co sobie wyobrażamy.

Bartleby jako widmo rzuca wyzwania i stwarza efekty. W tym artykule skoncentruję się na jednym z przejawów, na jednym $\mathrm{z}$ efektów: na władzy (i oporze), a może na oporze (i władzy). Mój tekst składa z dwóch 
części. W pierwszej zostaje przeprowadzona analiza opowiadania Hermana Melville'a pod tytułem Kopista Bartleby. Historia $z$ Wall Street, koncentrująca się na diagramie władzy. W części drugiej zastanowię się nad edukacyjnymi użytkami z takiej wizji władzy i oporu. Bartleby jest postacią, która pojawia się w rozważaniach nad innym ujęciem edukacji (Lewis, 2013; Vanhoutte, 2014; Agamben, 2018; Szwabowski, 2015, 2017a, 2018). Problematyka zaś władzy widzenia i mówienia w edukacji stanowi przedmiot zainteresowania zwłaszcza w pedagogice krytycznej (zob. Szkudlarek, 2009; Stańczyk, 2010, 2013; Monahan, Torres, 2010; McLaren, 2015; Chutorański, Szwabowski, 2017). W tekście postaram się sproblematyzować zarówno wykorzystanie Lewisa, jak i kwestię władzy oraz oporu. Ze względu na ograniczenia, jakie stawia forma artykułu, rozważania mają dość szkicowy charakter i zdaję sobie sprawę z konieczności pogłębienia niektórych kwestii.

\section{Czytając (z) Bartleby'ego/m}

Z jednej strony, mówienie - „usta”, z drugiej strony, widzenie - „oko”, te dwa mechanizmy stanowią elementy diagramu władzy i jako takie powinny być rozpatrywane jednocześnie, jako mechanizmy ujarzmiania, nadzorowania, normalizowania i określania. Ustanawiane jest zarówno pole wypowiedzi, z określonymi regułami, włączania i wyłączania, jak również pole widzialności, również z określonymi regułami. „Diagram sił aktualizuje się równocześnie w obrazach-opisach w krzywych-wypowiedziach" (Deleuze, 2004, s. 109). Słowo-obraz, wypowiedź-widzialne, usta i oczy - bycie w polu władzy, to bycie widzialnym, przedstawianym, ale też opisywanym, wypowiadanym. To również mówić, jak i jawić się - i odwrotnie: milczeć i znikać, czynić się niewidocznym i niewypowiedzianym, czyli wymykać się władzy. Pułapka widzialności i zeznania/przesłuchania, aby sprawnie funkcjonować, powiązana jest $\mathrm{z}$ władzą suwerena. Zarówno oko, jak i usta są uzbrojone ${ }^{1}$.

1 W tym kontekście warto przytoczyć cytat Foucaulta, który wskazuje, że interpretacje linearnego przejścia, zastępowania jednej władzy przez inną, są nie do końca do przyjęcia: „Nie ma czegoś takiego jak epoka prawa, epoka dyscypliny i epoka bezpieczeństwa. Nie jest tak, że mechanizmy bezpieczeństwa wkraczają na miejsce mechanizmów dyscyplinarnych, które wcześniej zastąpiły zespół mechanizmów prawno-jurydycznych. W grę wchodzi tu raczej seria złożonych konstrukcji, w obrębie których zachodzą, oczywiście, zmiany na poziomie samych, wciąż udoskonalanych, a w każdym razie komplikujących się technik, jednak tym, co najistotniejsze, jest zmiana każdorazowej dominanty albo sposobu korelacji między mechanizmami prawnymi, dyscyplinarnymi i tymi związanymi z bezpieczeństwem” (Foucault, 2014, s. 31; por. Raunig, 2009). 
W tej części artykułu przyjrzę się funkcjonowaniu diagramu władzy w tekście Kopista Bartleby. Historia $z$ Wall Street autorstwa Hermana Melville’a. Jednocześnie mam świadomość, że prowadzona przeze mnie narracja jest jedną z możliwych dróg użycia Bartleby'ego. Moja świadomość nie wynika tylko $\mathrm{z}$ określonych założeń metodologicznych, zrywających $\mathrm{z}$ poszukiwaniem prawdy tekstu na rzecz czynienia $\mathrm{z}$ niego użytków, ale również $\mathrm{z}$ charakteru samego głównego bohatera. Armin Bevenrungen i Stephen Dunne, przyglądając się próbom interpretacji Bartleby’ego, stwierdzają, że zawsze się wymyka, że zawsze zostaje coś ekstra, że jest on enigmą, tajemnicą (Bevenrungen, Dunne, 2007). W pewnym sensie, jako czytelnicy, stajemy się narratorami, pojawia się u nas pragnienie poznania, przeniknięcia tajemnicy, odkrycia słowa i ujrzenia Bartleby'ego takim, jakim jest, jakim jest naprawdę. Nasze oczy, nasze usta, nasze pragnienia, stają się tym samym pragnieniem władzy. $Z$ tego też powodu warto odwrócić relacje, stanąć po stronie milczenia i nie-widoczności, analizując same relacje władzy i oporu, efekty działań, wydarzenie biurowe. Zresztą niepoznawalność, niepewność co do Bartleby’ego podkreśla na wstępie już sam narrator:

O ile w przypadku innych kopistów potrafiłbym w pełni przedstawić ich żywoty, o tyle w przypadku Bartleby’ego jest to niemożliwe. Sądzę, że nie istnieją materiały pozwalające napisać pełną i zadowalającą jego biografię. To dla literatury strata niepowetowana. Bartleby należy do tych ludzi, o których niczego nie da się powiedzieć na pewno, chyba że na podstawie źródeł oryginalnych, a tych w jego przypadku mamy bardzie niewiele (Melville, 2009a, s. 7).

Zacznijmy od samego początku, rzeczy wręcz oczywistej: narratorem jest prawnik, szef Bartleby’ego. Tym samym to nie Bartleby jest tym, kto opowiada swoją historię. „Swoją”, bo osobisty kopista milczy; „swoją”, bo poza pewną plotką, która pojawia się na końcu opowieści, opowieść dotyczy relacji, spotkania szefa z tym dziwnym pracownikiem. Całkiem zresztą możliwe, że jest to nie tyle książka o Bartlebym, ile o właścicielu kancelarii ${ }^{2}$. Niemniej to prawnik staje się gwarantem prawdy o osobliwym kopiście ${ }^{3}$. Mamy dostęp tylko po-

Na marginesie warto też zwrócić uwagę na interesujące połączenie tych trzech władz w pisarstwie Coetzee, zwłaszcza w Czekając na barbarzyńców (zob. Canepari-Labib, 2005).

2 Bartleby’ego można potraktować jak widmo. Nie tylko jeżeli chodzi o dynamikę widzialności i niewidzialności, ale w sensie tworzenia widma przez widzącego: „Widmo jest również tym, co ktoś sobie wyobraża, co sądzi, że widzi i co projektuje, co rzutuje na wyobrażeniowy ekran - tam, gdzie niczego nie widać" (Derrida, 2016, s. 169). Bartleby jest przecież usytuowany wewnątrz oka, za powiekami, w kącie oka. Zarówno widzialny, jak i niewidzialny. Niewidzialność podkreśla zasłonięcie go, skrycie go za parawanem. Dodatkowo, to, co jest istotne w widmowej egzystencji osobliwego kopisty, to podkreślany efekt widma. To ono nas widzi. Obserwuje, nawiedza i daje do myślenia.

3 Zgadzam się w tym miejscu z Danem McCallem, postulującym traktowanie narratora jako wiarygodnego. „Ale jeżeli nie bierzemy narratora poważnie, nigdy nie będziemy mogli wziąć Bartleby’ego poważnie” (McCall, 1989, s. 113.) 
przez jego słowo i jego oczy, które usytuowane są w człowieku solidnym, co podkreśla sam narrator. Zakładam, że nie oszukuje on nas bardziej niż siebie, kiedy opowiada o Bartlebym. Prawda, którą chce wyrazić prawnik, związana jest z oczami, to oczy stają się źródłem poznania:

Nie wiem o Bartlebym nic ponad to, co ujrzałem na własne zdumione oczy, kiedy miałem z nim osobiście do czynienia, oraz nie licząc jednej niejasnej relacji, która pojawi się w dalszym ciągu tej opowieści (Melville, 2009a, s. 7) .

To, co „jego zdziwione oczy zobaczyły”, „to wszystko, co wie o nim”. Odwołanie się do wzroku, że „to wszystko” się zobaczyło, z jednej strony można potraktować jako gwarancję rzetelności narratora, nie dodaje niczego, czego moje oczy nie zobaczyły, czego sam nie byłem świadkiem, żadnych domysłów, żadnych plotek - poza „niejasną narracją” na samym końcu, do której jeszcze wrócę. Wpisywałby się tym samym w kartezjańsko-oświeceniową tradycję uprzywilejowującą zmysł wzroku (Swoboda, 2010, s. 12). Z drugiej może wskazywać na subiektywność, na niedostępność Bartleby’ego. No był taki w moich oczach, on się mi takim jawił, tak mi się prezentował. I to nie prezentował się ogólnie jako przedmiot spojrzenia, ale przedmiot spojrzenia konkretnych my own - oczu.

Można powiedzieć, że jedna i druga strona, obiektywność spojrzenia i subiektywność partykularnych oczu, łączą się: uprzywilejowany zmysł pokrywa się z uprzywilejowaną perspektywą patrzącego. Prawnik ucieleśnia spojrzenie władzy ustanawiającej obiektywność kapitalistycznego porządku społecznego $^{5}$. Uprzywilejowanie przejawia się między innymi w tworzeniu przestrzeni widzialności, przestrzeni samego biura:

moją kancelarię dzieliły na dwie części rozsuwane drzwi z wstawionym matowym szkłem - jedną zajmowali kopiści, drugą ja. W zależności od samopoczucia, raz drzwi szeroko rozsuwałem, raz zamykałem (Melville, 2009a, s. 17).

4 „What my own astonished eyes saw, that is all I know of him, except, indeed, one vague report, which will appear in the sequel" (Melville, 2009b, s. 2).

5 Robert T. Schultz wskazuje na ten kapitalistyczny charakter spojrzenia. Wprawdzie nie jak Ozimek, przypisując narratorowi złe intencje i negatywne cechy burżuazyjnego wyzyskiwacza, ale po prostu jako pozycji społecznej, gdzie wzrok nie jest czymś naturalnym, ale ma charakter klasowy. Ten klasowy charakter ujawnia się przede wszystkim w uprzywilejowaniu spojrzenia pracodawcy jako tego, kto tworzy narracje o pracownikach, ale też w samej naturze tejże narracji, czyli spojrzeniu utowarawiającym, kierowanym logiką kapitalistyczną, a sam kapitalizm staje się bytem jako takim (Schultz, 2011). Również Naomi C. Reed podkreśla klasowy charakter narratora i jego wpływ na postrzeganie, działanie i mówienie. Sam język traktowany jest przez niego jak pieniądz (Reed, 2004, s. 262; zob. też Bush, 1990). 
Możliwość rozsuwania i zasuwania drzwi w zależności do nastroju, woli stanowi przejaw władzy - to prawnik decyduje, kiedy patrzy i kiedy podmioty są widziane, tak samo jak to on ma przywilej stawania się niewidocznym. Jak zauważa Szymon Ozimek:

Zamykanie i rozsuwanie drzwi nie jest i nie może być funkcją dobrego lub złego humoru prawnika-narratora. Jest emanacją jego nadzorczej, wizualnej władzy (Ozimek, 2011, s. 2011).

Ozimek wprawdzie odrzuca tłumaczenie samego prawnika, stwierdzając, że nie ma to nic wspólnego z „humorem” narratora, ale jest perfidnie zaplanowaną przestrzenią nadzoru i permanentnej kontroli. Biorąc pod uwagę diagram władzy, jedno nie wyklucza drugiego. Wręcz przeciwnie: „humor” jako wola i możliwość jej realizowania wpisany jest we władzę - podkreśla suwerenną władzę nad poddanymi, którzy takiej woli manifestować nie mogą.

Warto zauważyć, że samo widzenie podmiotów jest przejawem urzeczowienia, trzech kopistów - Indyk, Szczypce oraz Pierniczek - opisywanych pod kątem przydatności do pracy, ich cechy wyodrębnione tak, jakby osoby stanowiły ich zbiór, są również odnoszone do pełnionej profesji.

W przypadku wymienionych kopistów oko władzy narratora czyni typowe użytki, nie przekracza własnego pola widzenia, przymykając się zgodnie z panującymi regułami:

(...) pod wieloma względami uważałem go [Indyka] za człowieka bardzo wartościowego, który aż do godziny dwunastej w południe, zenitu dnia, ani przez minutę nie przestawał być najszybszą i najbardziej zrównoważoną istotą ludzką, wykonującą ogrom pracy w stylu, jakiemu niełatwo by dorównać - oto dlaczego przymykałem oko na wszelkie jego dziwactwa (Melville, 2009a, s. 11).

Otwierania drzwi-oka, przymykanie oka, widzenie-kalkulowanie. To spojrzenie dopełniają słowa, wzmacniają urzeczowiający dyskurs. Już w pierwszych słowach można dostrzec, że narrator używa języka, który wskazuje na posiadanie: my employés, my business, my chambers (Melville, 2009b, s. 2). Określa się w pozycji nadrzędnej względem pracowników, którzy są jego i określają jego osobę. Prawnik swoją bezpieczną pozycję solidnego człowieka opiera na przychylności Johna Jacoba Astora, który „nie wahał się oświadczyć, że moja pierwsza wielka zaleta to roztropność, a druga - metoda” (Melville, 2009a, s. 9). Rekomendacja o narratorze i jego roztropności oraz metody jako sposobu postępowania związana jest $\mathrm{z}$ „,brzękiem sztab złota”. Roztropność i metoda stanowią przejaw racjonalności kapitału, jego cyrkulacji: „krągłość brzmienia i słychać w nim brzęk sztab złota” (Melville, 2009a, s. 9). Tak jak jego pewność, bycie bezpiecznym - safe man.

Dla spojrzenia i mowy prawnika kopiści są przejrzyści: „potrafiłbym w pełni przedstawić ich żywoty" (Melville 2009a, s. 7). Nie stanowią wyzwania, do- 
pasowują się - przestrzeń jest jasno wydzielona: drzwi się otwierają, drzwi się zamykają ${ }^{6}$.

Sytuacja ulega zmianie, gdy pojawia się Bartleby. Co istotne, nie zostaje on jednoznacznie włączony do sfery pracowniczej za powiekami-drzwiami, ale wewnątrz przestrzeni pracodawcy, jednocześnie zostaje odcięty od prawnika zielonym parawanem. Nie pozostaje on wyłączony $z$ władzy słowa-spojrzenia, niemniej staje się dla tego oka i ust władzy wyzwaniem. Z jednej strony jest tym, który się jawi, o którym się opowiada. Ozimek stwierdza wręcz, że spojrzenie władzy towarzyszy Bartleby’emu aż do śmierci - prawnik staje się „świadkiem i gwarantem” jego zgonu (Ozimek, 2011, s. 127). Mało tego, nawet po śmierci. Gdy Bartleby umiera, pojawia się (appear) doniesienie po to, aby znowu uczynić kopistę widzialnym. Relacja, niejasna, niemal widmowa, znowu czyni kopistę widocznym, jawiącym się, widmowym znakiem, już bez podmiotu, odniesienia do istnienia, a jedynie do resztek, które cyrkulują po śmierci (Reed, 2004, s. 264). Nawet kiedy oczy nie dostrzegają postaci, to słowa o Bartlebym się jawią. To jawienie się, to spojrzenie, nie jest już tak jasne w kontekście relacji władzy. Pojawia się tutaj rysa, która wskazuje, że odczytanie Ozimka jest zbyt „marksistowskie” w klasycznym znaczeniu, które poddał krytyce chociażby McCall. Ozimek między innymi nie dostrzega specyfiki Bartleby'ego, redukując go do po prostu wyalienowanego pracownika biurowego - to, co unikatowe, specyficzne, pojedyncze, zostaje zastąpione przez przykład. Tymczasem w przeciwieństwie do innych kopistów „Bartleby należał do tych ludzi, o których niczego nie da się powiedzieć na pewno”(Melville 2009a, s. 7). Niemożliwość powiedzenia czegoś na pewno o osobliwym kopiście podkopuje pewność samego narratora. Nie tylko zostaje on zobaczony, ale to on, Bartleby, jawi się oczom prawnika. Drzwi były otwarte i sam przez nie wszedł. To ta druga strona. Jak zauważa Krips, Bartleby sprawia, że pracodawca zaczyna wątpić we własną zdolność widzenia (Krips, 2012, s. 312).

Bartleby zjawia się i uwodzi. Coś w nim sprawia, że prawnik przyjmuje go bez referencji, ulokowuje blisko siebie, w przestrzeni oka władzy, a nie w przestrzeni podmiotów będących przedmiotem nadzoru. Oczywiście prawnik uruchamia narrację kapitalistyczną, retorykę stosowaną wobec poprzednich swoich pracowników: „człowiek o tak wyjątkowo spokojnym charakterze, co, jak pomyślałem, będzie miało dobroczynny wpływ na nerwowe usposobienie Indyka i zapalczywe Szczypiec" (Melville, 2009a, s. 17). Ulokowanie za parawanem tłumaczy faktem, że dzięki temu sprawniej będzie przebiegać praca. Ale

6 Są przejrzyści, bezproblemowi, może też dlatego, że radzą sobie z alienującą pracą, z byciem ludzką maszyną, w sposób, który jest społecznie uznany. Drobne dziwactwa, z którymi wiadomo, co robić. Powodem agresji i niechęci innych pracowników wobec Bartleby’ego może być również to, że stosuje inne formy oporu niż alkoholizm. 
ton ulega lekkiej zmianie, można wyczuć, że prawnik nie wypowiada wszystkiego, nie dlatego, że kłamie, ale dlatego, że jeszcze tego nie dostrzega: swoista bliskość - szybkość, z jaką go zatrudnia, niezatarte wrażenie pierwszego spotkania, jak i niespodziewane przemeblowanie. Ta dziwna bliskość rzuca światło na tolerowanie przez prawnika dziwnego zachowania swojego pracownika, jak również na moc efektu, jaki wytwarza jego nie-działanie. Jak zauważa wspomniany Krips, Bartleby uruchamia rejestr właściwy dżentelmenom, przez co wprowadza inny porządek do porządku pracy, doprowadzając oba do drżenia, zastygnięcia - jest to swoisty gest rozbrajający oba prawa. Pracodawca, chcący uchodzić za dżentelmena, a zarazem będący pracodawcą, zostaje ujęty w kleszcze przez oba dyskursy, unieruchomiony zostaje on, jak i zakleszczone dyskursy. Tej bliskości rejestru dżentelmenów towarzyszy rozpoznanie w Bartlebym kogoś jemu bliskiego. Nie jest w stanie rozpoznać tej bliskości, mimo że sam osobliwy kopista podsuwa mu odpowiedź, gdy na pytanie, dlaczego przestał kopiować, odpowiada pytaniem: „A sam pan tego powodu nie dostrzega?” (Melville, 2009a, s. 37).

Bartleby się zjawia i zostaje dostrzeżony; prawnik snuje o nim relację, ale nie może niczego o nim powiedzieć; zatrudnia go, a ten skotłuje biuro. Miesza języki i mąci wzrok. To, co Ozimek i inni twardogłowi marksiści ${ }^{7}$ widzą jako działanie władzy, ja widzę jako przejaw oporu. Pierwsze wypowiedzenie I would prefer not to jest momentem zacięcia się maszyny kopiującej i zainicjowaniem nowego sposobu działania, czy precyzyjniej: zacięcie się, zobrazowane powtarzaniem (się) I would prefer not to wytwarzać zaczyna inne efekty. Bartleby staje się siewcą chaosu i zniszczenia (Schultz, 2011, s. 587-588; Deleuze, 2009, s. 124-125). Mamy do czynienia nie tyle może z kontr-panoptikonem, ile $\mathrm{z}$ panoptikonem na jałowym biegu, panoptikonem $\mathrm{z}$ wadą wzroku, panoptikonem nawiedzonym, panoptikonem zawieszonym między jawą a snem, panotpikonem halucynującym.

Dopiero dynamiczne ujęcie władzy i oporu, w ich relacji i obcości, otwiera pole do zrozumienia funkcjonowania samej władzy i specyfiki oporu, jaki prezentuje Bartleby. Zacięcie się maszyny kopiującej dostrzeżone jest przez adwokata jako coś, co przychodzi z zewnątrz, z innego porządku. W oporze przejawiającym się w powtarzaniu - preferuje nie ${ }^{8}$ - Bartleby'emu jawi się jakaś obca, nieludzka siła, tak jakby coś nad Bartelbym panowało, jakby został

7 Pod pojęciem „twardogłowych marksistów” rozumiem tych interpretatorów, którzy nakładają na tekst uproszczoną wersję marksizmu. U Ozimka dodatkowo działa „ludowa” wizja konfliktu klasowego, co widać w jego interpretacji narratora (o ograniczeniach „klasycznych” interpretacji marksistowskich zob. Reed, 2004, s. 247-248).

8 Jak zauważa tłumacz Sławomir Królak, jest to lepsze tłumaczenie I would prefer not to ze względu na brak odniesienia do woli, co ginie w polskim tłumaczeniu „woleć nie”. Polskie 
poddany innej władzy i dlatego nie mógł postępować zgodnie z racjonalnymi przesłankami podawanymi przez pracodawcę. Jednocześnie to, co nawiedziło Bartleby’ego, dosięga też adwokata. Tak jak już wspomniałem, traci on pewność siebie, pewność własnego ulokowania, opuszcza go roztropność, zawodzi metoda. Pojawiają się plotki mogące zaszkodzić jego reputacji. I przez Bartleby’ego nie odwiedza kościoła. I tak przez Bartleby’ego traci pewność wzroku, miesza mu się język.

Tak się jakoś złożyło, że ostatnimi czasy nabrałem zwyczaju mimowolnego używania wyrazu „woleć” przy wszelkich, nie zawsze stosownych okazjach. Drżę też na myśl, że kontakt z kopistą już zdążył poważnie odcisnąć się na mojej psychice (Melville, 2009a, s. 36).

Z przerażeniem stwierdza, że nie tylko on nabrał dziwnej maniery, ale również inni pracownicy, nieświadomie, zaczęli „preferować”.

Kiedy otwierał rozsuwane drzwi, opuszczając nas, Szczypce znad swego biurka spojrzał na mnie i zapytał, czy wolałbym, aby skopiował pewien dokument na papierze niebieskim czy białym. Nie wypowiedział wolałbym zaczepnie. W sposób oczywisty ześlizgnęło się ono z jego języka bez złej woli. Pomyślałem, że najwyższy czas, by pozbyć się upośledzonego umysłowo, który już w jakimś stopniu pomieszał języki, a może i umysły, i mnie, i mym kancelistom (Melville, 2009a, s. 37).

Bartleby jako ten, który miesza umysły i języki, ten, który burzy spokój, jest niczym szczelina, otchłań. Kiedy w nią spoglądamy, zmianie ulega nasza percepcja. Mając świadomość jej istnienia, wiemy, że system jest niedomknięty, jest kruchy, arbitralny. Wszelkie fundamenty mogą się osunąć w otchłań, ukazać swoją nicość, na której zostały zbudowane. Wypowiadane przez Bartleby'ego I would prefer not to działa niczym magiczna formuła, odsłaniająca prawdę ukrytą pod konwencjonalnymi nazwami i codziennymi sposobami użycia. Deleuze opisuje jej działanie następującymi słowami:

Formuła pączkuje i rozrasta się. Za każdym razem, gdy Bartleby jej używa, wprawia w osłupienie pozostałych, którzy zachowują się, jakby zbliżali się do Niewyrażalnego albo Nieuchronnego. Jest nim milczenie Bartleby’ego, zupełnie jakby powiedział wszystko i tym samym wyczerpał możliwość języka. Każdej takiej sytuacji towarzyszy wrażenie wzmagającego się szaleństwa: nie chodzi tu o szaleństwo Bartleby’ego, lecz o to, które wzbudza u pozostałych - szczególnie u adwokata, który w efekcie składa dziwne propozycje i jeszcze dziwniej się zachowuje (Deleuze, 2009, s. 67-68).

Wyrwa, którą tworzy wypowiedź Bartleby’ego, wprowadza adwokata w niebezpieczny stan, otwiera przed nim perspektywę niewłaściwą dla ludzi jego stanu. „Po raz pierwszy w życiu ogarnęło mnie uczucie dominującej melan-

tłumaczenie czyni wtedy niektóre użytki z Bartleby’ego niezrozumiałymi. Między innymi odczytania Agambena czy Lewisa (zob. przypis tłumacza nr 3, Agamben, 2009, s. 127). 
cholii. Nigdy przedtem nie doświadczyłem choćby odrobiny tak dotkliwego smutku" (Melville, 2009a, s. 31). Melancholia z jednej strony odrywa adwokata od panujących stosunków społecznych, $z$ drugiej otwiera go na doświadczenie braterstwa - zupełnie innych relacji, zupełnie innej rzeczywistości. „Krążyły wokół mnie przeczucia dziwnych odkryć" (Melville, 2009a, s. 32). Gdyby jednak podążył drogą otwartą przez Bartleby’ego, straciłby to wszystko, co tworzy jego podmiotowość, na czym oparta jest jego wiara w siebie i w świat, poczucie własnej wartości. Obietnica jest zagrożeniem. W pewnym sensie Bartleby jest nie tylko prześwitem (Deleuze, 2009, s. 138), bramą, ale również murem ujawniającym ograniczenia samego adwokata (Springer, 1965).

Do końca już nie wiadomo, kto jest w czyjej władzy. Kto na kogo spogląda, kto kogo tworzy poprzez słowo. Może to nie jest tutaj wcale istotne. Tego chyba nauczył nas Foucault. Tego, że władza jest relacją, w ramach której wiążą się podmioty.

Warto zadać sobie pytanie, dlaczego prawnik-narrator tak bardzo chce poznać tajemnice Bartleby'ego? Skąd to obsesyjne dążenie? Wiemy znowu od Foucaulta, że władza nie tyle skazuje na milczenie, ile namawia do mówienia. Władza namawia do mówienia, bo nie może znieść braku wiedzy - to, co nierozpoznane, wymyka się jej, pozostaje poza kontrolą. Życie bez znaczeń wydaje jej się czymś potwornym, a to ona jest znaczeń strażnikiem. W tym kontekście milczenie jest nie tyle przyzwoleniem na nadawanie znaczeń, ile ukazaniem niemożliwości pełni władzy, jej braku, niepełności, tego, że zawsze coś jej się wymyka. Wydaje się, że ten problem dobrze obrazuje sytuacja Piętaszka opisana w Foe. Piętaszek nie mówi, bo nie ma języka, został mu odcięty - chyba trudniej wyobrazić sobie lepszy przykład działania władzy. Taki akt czyni go pozornie bezbronnym wobec władzy języka, jak podkreśla Susan Barton podczas rozmowy z pisarzem:

Piętaszek nie włada słowem, przeto nie umie się bronić przed transformacjami, którym dzień po dniu ulega zgodnie z życzeniami innych ludzi. Rzeknę, że jest kanibalem, i kanibalem się staje; rzeknę, że jest pomywaczem, i oto już mamy pomywacza (Coetzee, 2007, s. 121).

Zaraz jednak pojawia się pęknięcie: „Gdzież tedy prawda o Piętaszku?” świadomość, że nie jest on żadnym z tych określeń, że się wymyka. Niewiele pomaga odwołanie się do władzy spojrzenia, ono nie przenika do wnętrza, ześlizguje się - a Piętaszek tańczy. Poznanie prawdy o Piętaszku nie jest tylko kwestią jego wyzwolenia, ale też wyzwolenia się od niego. Unieruchomienia, wprowadzenia do archiwum. Podobnie jest z Bartlebym. Władza mówienia staje tutaj wobec paradoksu, który ukazuje jej niemoc. Niezależnie od tego, co prawnik mówi, słowa się odbijają, krążą pozornie swobodnie, nie są jednak w stanie nadać sensu osobliwemu kopiście. Wydaje się, że rozwiązaniem jest jedynie naga przemoc, przed którą jako dobry chrześcijanin się powstrzymuje. 
Tylko że naga przemoc również niewiele pomaga mocy dyskursu jako próbie poznania. O ile istnieje coś, co się wymyka i majaczy, fizyczne nie-niefizyczne obecności wprawiać będą głos w drżenie ${ }^{9}$.

Prawnik stara się go oswoić, uczynić listem $\mathrm{z}$ adresem, po to, aby móc się go pozbyć i tym samym wzmocnić władzę, którą naruszył swoim pojawieniem się. W tym sensie reprezentuje władzę, działa dla sprawy porządku i przetrwania własnej tożsamości - swojego ja. Słusznie zauważa Lorenz, że w tej grze nie ma miejsca dla Bartleby’ego - musi on zostać usunięty (Lorenz, 2005, s. 75): tak albo inaczej. Nie zauważa jednak, że Bartleby uruchamia inną grę, w którą wciągnął prawnika: grę innego świata, podążania za widmem, szaleństwa utopii. Życia jako śmierci, to znaczy: wyparte życie jawi się jako śmierć. Wciągniecie jej do gry może pozwolić zmartwychwstać. Lecz wtedy nie chodzi już o prawdę, ale o podążanie, nie o zamykanie w znaczeniach i spojrzeniach, ale otwieranie.

Warto wspomnieć, znowu przeciwko twardogłowym marksistom, że narrator nie jest zimnokrwistym kapitalistą, jest „pozbawionym ambicji prawnikiem", wokół którego buduje się kapitalizm, wysokie budynki, a on sam pozostaje raczej $\mathrm{w}$ narracji drobnego przedsiębiorcy domowej firmy. Stara się być dobrym obywatelem, nie zaś znaleźć się w biurze na najwyższym piętrze najwyższego budynku. Wskazuje na to między innymi Norman Springer, adwokat nie jest wulgarnym, ograniczonym przedsiębiorcą, kochającym jedynie pieniądze, ale jest wykształconą osobą, świadomą moralnych problemów (Springer, 1965, s. 410). Te cechy wskazują na niepełne zintegrowanie z systemem, na pękniecie, w którym objawia się widmo-Bartleby jako zagrożenie i obietnica. To z kolei czyni go podatnym na nawiedzenie. Dopóki jednak używa sfetyszyzowanego języka, nie jest w stanie na nie dopowiedzieć (Reed, 2004, s. 263-264).

9 Przykładowo zamknięcie Bartleby’ego w więzieniu nie przyczynia się do lepszego poznania. Gdyby zaś przyjrzeć się sytuacji opisanej przez Coetzee w Czekając na barbarzyńców, która to książka stanowi rozważania na temat poznania, przemocy i inności, to również dostrzeżemy bezradność władzy ukrytą za jej festiwalem okrucieństwa. Wprawdzie pułkownik Joll uważa, że jest w stanie wydobyć prawdę, odpowiedni „głos prawdy”, do której to prowadzi przemoc - „Tylko ból jest prawdą” (Coetzee, 2003, s. 11), ale tortury jedynie wydobywają to, co on chce usłyszeć, potwierdzają jego wizję świata i iluzję dotyczącą barbarzyńców: „poprzez tortury Imperium pisze i stwarza barbarzyńców" (Canepari-Labib, 2005, s. 141). Wytwarza głos jednostki i ciało, jednocześnie przepisuje, pozbawia, redukuje, kontroluje, stwarza; są to zabiegi dostosowania, przekształcania ciał, języków i samej rzeczywistości, „aż potwierdzi ich wersję prawdy” (Canepari-Labib, 2005, s. 142). Prawdy Imperium. Imperium poprzez język i przemoc, które są z sobą splecione, może jedynie stwarzać świat, ale ten, co ukazuje zakończenie Czekając na barbarzyńców, jest potężniejszy od ich prawdy. 
Może rzeczywiście zamkniecie oczu, jak chce Ozimek, jest ostatnim aktem władzy nad Bartlebym, ale smutek prawnika nie jest udawany. Kolejne, ostatnie nawiedzenie, kiedy Bartleby pojawia się już jako zjawa, słowo, plotka, kończy się okrzykiem, po którym zapada milczenie. Narracja się urywa. Nie tyle zostaje zakończona, ile urwana - tak jakby emocje, przez szczeliny i pęknięcia stworzone przez Bartleby’ego wyrwały się z dyskursów... i uruchomiły linie ujścia? Czy też prawnik zastygł nieruchomo, wpatrzony w martwy mur?

\section{Nawiedzeni edukatorzy i obłąkani studenci}

Wiosną 2010 roku amerykańscy uczniowie zainicjowali ${ }^{10}$ The Bartleby Project, w którym nawołują do oporu wobec ustandaryzowanych testów (http://www. bartlebyproject.com/). Akcja ma mieć charakter pokojowy, polegający na odmowie inspirowanej postacią Bartleby'ego. $\mathrm{W}$ promującym inicjatywę filmie stwierdzają, że zniszczenie systemu ustandaryzowanych testów jest możliwe dzięki lekcji, jakiej udziela Herman Melville. Zachęcają uczniów do napisania ośmiu prostych słów na górze strony: I would prefer not to take your test. Dodatkowo instruują uczestników, że jeżeli zostaną zapytani o powód swojej odmowy wypełnienia testu, powinni po prostu odpowiedzieć: I prefer not to say why. Taka odmowa może wywołać histeryczną reakcję nauczycieli, od strategii grożenia, przez zachęcanie, błaganie, po odwołanie się do poczucia obowiązku, ale tak naprawdę będą bezradni (zob. The Bartleby Project 2010). Mało tego, sami mogą przestać narzekać na panujący system i przyłączyć się do ruchu oporu (TeachersCount Blog).

Bezpośrednią inspirację dla projektu stanowiła książka Johna Taylora Gatto, Weapons of Mass Instruction (Gatto, 2010), której fragment został zamieszczony na stronie internetowej The Bartleby Project jako forma manifestu. Gatto zaprasza do „otwartej konspiracji” mającej na celu zniszczenie systemu ustandaryzowanych testów, który niczym praca w biurze wykonywana przez Bartleby'ego jest dehumanizującą, destrukcyjną praktyką.

Gatto stwierdza, że „Bartleby jest ludzką maszyną kopiującą w czasach przed wynalezieniem zastępczej maszyny elektrycznej, słabo opłacaną, zaj-

10 Należy nadmienić, że autor projektu jest nieznany, uczniowie zostali zaproszeni tak po prostu. Sam projekt $\mathrm{z}$ założenia ma się odbywać poza wszelkimi oficjalnymi organizacjami, jest inicjatywą bez liderów, ekspertów i polityków. Zob. http://1080.plus/mobile/?jDTCcTMcEDc.video. John Taylor Gatto stwierdza, że projekt nie powinien być koordynowany, centralnie zarządzany, co uchroni go przed pochłonięciem przez system, przed korupcją. Zob. John Taylor Gatto’s Statement, The Bartleby Project; http://www.bartlebyproject.com/gatto.html (dostęp: 12.04.2018). 
mującą niską pozycję w kancelariach i przedsiębiorstwach. Pewnego dnia, bez ostrzeżenia czy wyjaśnienia, Bartleby zaczyna ćwiczyć wolną wolę" (John Taylor Gatto's Statement). Najpierw odmawia wykonywania tylko niektórych czynności, aby ostatecznie zaprzestać kopiowania w ogóle. To „ćwiczenie wolnej woli”, które stanowi spokojny, pozbawiony emocji opór wobec bycia traktowanym jak ludzkie narzędzie, ,jest bardziej rewolucyjny niż jakakolwiek rewolucja, która miała miejsce" (John Taylor Gatto’s Statement). Taka rewolucja, stwierdza Gatto, może położyć kres imperium testów. Teraz dopiero Gatto zrozumiał, co chciał powiedzieć Melville. A przynajmniej tak mu się wydaje.

Nie wchodząc w dyskusję o odpowiedniości interpretacji Gatto, mamy tutaj usytuowanie Bartleby'ego jako postaci opozycyjnej wobec edukacji traktowanej jako społeczna inżynieria (Ruitenberg, 2017), redukowania jej do technologicznej dydaktyki (Malewski, 2010). Bartleby nie przeciwstawia się jedynie zimnej maszynie „opartej na dowodach” i skoncentrowanej na mierzalnych efektach, ale też podważa neoliberalny paradygmat uczenia się.

Pozornie emancypacyjne podejście do edukacji związane $\mathrm{z}$ uczeniem się zostało poddane dość wnikliwiej krytyce (zob. Biesta, 2004, 2010; Simons, Masschelein, 2006; Starego, 2016). Zatrudnienie Bartleby’ego nie tylko wiąże się z jej pogłębieniem, lecz także wytworzeniem innej logiki. Lewis przeciwstawia uczeniu się, które traktuje jako technikę podporządkowywania pod biokapitalizm, studiowanie jako radykalnie odmienną praktykę edukacyjną, która nie jest podporządkowana żadnym celom ani nie sprowadza się do aktualizacji, ale raczej do celebrowania potencjalności (Lewis, 2013). Według Lewisa „studiowanie jest ponad mierzalnością i ponad predefiniowanym celem” (Lewis, 2014, s. 339). Tym samym student „powinien być przemyślany jako ten, który studiuje bez określonego celu, bez zidentyfikowanego interesu, przez co jest otwarty, wystawiony i troskliwy wobec świata" (Lewis, 2013, s. 13). Podejmując taką praktykę, zawiesza logikę biokapitalizmu. Takim idealnym studentem jest Bartleby. W opowieści Lewisa osobliwy kopista jest tym, który odmawiając pracy i celebrując nie-potencjalność, wycofuje się z maszyny edukacyjnej i klasyfikacji w ramach dominującego modelu edukacji. Wymykając się $\operatorname{logice}$ testowania i egzaminowania, próbom oceny, wycofując się z „logiki aktualizacji” (Lewis, 2013, s. 47), staje się nikim, bytem nieokreślonym, pozbawionym przyszłości oraz przeszłości. Jest istnieniem pozbawionym odniesienia do jakiejkolwiek społecznej roli. „Nie posiada żadnych preferencji, żadnej określoności, nie pożąda tego, by stać się x, y albo z" (Lewis, 2013, s. 50). Nie chce on być ani barmanem, ani sprzedawcą, pozostając otwartym na wszystkie profesje i jednocześnie wszystkie je jednakowo (nie) preferując. Zawiesza on obowiązywanie norm, otwierając nowe pola użytku. Podsumowując rozważania o studencie Bartlebym, Lewis stwierdza, że „Bartleby nie uczy nas, co 
pisać ani jak pisać, ale raczej tego, że możemy/nie możemy pisać” (Lewis, 2013, s. 52).

Odczytanie Lewisa nie sprowadza się jedynie do dostrzeżenia gestu zerwania, jaki czyni Bartleby, jego negatywnego efektu, rozsadzającego władzę, ale też proponuje pozytywną wizję. Wiążąc go z postawą radosnej melancholii, wyczerpania, wiecznego tracenia i gubienia, oscylowania pomiędzy wiedzą i nie-wiedzą, cyrkulowania w cyklach, z majsterkowaniem, potencjalnością i aktualizacją, pojmuje studiowanie jako zamieszkiwanie $\mathrm{w}$ progu i gubienie się $\mathrm{w}$ labiryncie (Lewis, 2013, 2014, 2017a, 2017b; D’Hoest, Lewis, 2015).

O ile uczenie się pomaga klasyfikować przedmioty pod względem ich umiejętności, deficytów, studiowanie deklasyfikuje przedmioty (czyni je nierozpoznawalnymi dla aparatów uczenia się). I jeśli uczenie się dotyczy aktualizacji i oszacowywania w celu optymalizacji wyników pod kątem identyfikacji społecznej i użytecznych form, to studiowanie preferuje nie poświęcać potencjalności w imię aktualizowania zbioru określonych zdań, zdolności, protokołów i tak dalej (Lewis, 2017b, s. 303).

Odniesienia studiowania nie ograniczają się jedynie do dydaktyki, ale również do samej pracy akademickiej. Lewis, analizując pracę badawczą Patti Lather's, stwierdza, że badania są formą studiowania. Jego zawieszeniem, rodzajem pauzy (Lewis, 2017b, por. D’Hoest, Lewis, 2015). Nie tylko więc Bartleby wywołuje efekt możliwości nie-pisania, ale też tworzenia nie-raportów (D’Hoest, Lewis, 2015), nie-badań (Lewis, 2017b).

W narracji Lewisa studiowanie stanowi przede wszystkim radykalnie odmienne doświadczenie egzystencjalne. Zdają się nie istnieć wspólny język, wspólne działanie, wspólne pragnienia. Stąd próby łączenia studiowania z uczeniem się i nauczaniem nie są przekonujące i nie dostrzegają specyfiki nowego paradygmatu (Ford, 2016). Bartleby jako idealny student nawiedza instytucje edukacyjne i czarnym słońcem oświetla zarówno wyalienowany charakter pracy akademickiej, jak i rozbudza pragnienie exodusu.

Wspomniani pedagodzy ujmują Bartleby'ego jako przejaw oporu, nie zaś ofiarę władzy, czy też mówiąc bardziej precyzyjnie, nie tylko jako ofiarę. Bartleby nie jest jedynie obrazem alienacji i dehumanizujących warunków pracy (Palmerino, 2011) oraz przejawem zafiksowania na ograniczeniach (Marx, 1953). Wprawdzie poprzez swoje nawiedzenie ujawnia nekrofilny charakter (akademickiej) produkcji (zob. Szwabowski, 2019), nie wyczerpuje się jednak w tym, co negatywne. Jest on jednocześnie szczeliną, która zwiastuje coś innego. Prześwitem i utopią, linią ujścia, która pojawia się nie tyle jako efekt władzy, ile staje przed murem i poza murem, dowodząc, że „[w]szelkie formy rządzenia są skazane na klęskę" (Wilde, 2019, s. 22). Opór jest więc pierwotny względem władzy, a milczenie, o którym mowa, i niewidoczność nie są jej 
efektem, ale granicą mocy (zob. Deleuze, 2004; Deleuze, Guattari, 2015; Pacewicz, 2015).

Te bliskie mi odczytania są jednak problematyczne. Po pierwsze, Bartleby jest nam znany jedynie z perspektywy władzy, to jest opowieść tego, kto nie-widzi osobliwego kopisty, kogoś, kto jest nawiedzony, ale nie wie, a może nie chce wiedzieć, przed jakim wyzwaniem został postawiony. Oznacza to, że Bartleby zaczyna się po końcu opowiadania, w momencie urwania się narracji. Tym samym dyskusyjne jest opieranie się na obrazie majaczącego widma jako pozytywnym obrazie. Po drugie, zarówno Gatto, jak i Lewis zdają się redukować Bartleby’ego. Pierwszy do własnych o(d)porowych pragnień i praktyk, drugi do interpretacji agambenowskiej, na którego koncepcji filozoficznej opiera swoją koncepcję studiowania (zob. Agamben, 2018).

Lewis, opierając się na Agambenie, reprodukuje również jego perspektywę teoretyczną, produkując tym samym metafizyczną wizję studiowania. O ile Agamben nie jest w stanie zupełnie zerwać z metafizyką (zob. Bednarek, 2012), o tyle Lewis wręcz ją wzmacnia. Prowadzi to nie tylko do samego napięcia $\mathrm{w}$ myśli Lewisa i problemu pogodzenia idealnego studenta $\mathrm{z}$ kolektywnym Bartlebym w ramach Ruchu Occupy (Lewis, 2013; na temat kolektywnego Bartleby'ego zob. Szwabowski, 2016, 2017b), nie tylko do niedostrzegania klasowych, genderowych i rasowych problemów (D’Hoest, 2017), lecz także do niemożliwości zerwania $\mathrm{z}$ podążaniem linią ujęcia, dokonania realnego exodusu. Pomijam kwestię tworzenia złudzenia, że edukacja posiada własną logikę, daną przez samą naturę, świat, a nie jest jedynie czy aż czymś rozproszonym, modyfikowanym i wytwarzanym w ramach określonych założeń.

Kluczowym problemem $\mathrm{z}$ nawiedzeniem Lewisa jest to, że przyjmuje on obraz władzy jako obraz oporu. Zatrzymuje się na tym, co jest widoczne, dostrzegając w tym przejaw utopii, a nie odbicie tego, co jest. Tymczasem widmo-Bartleby jest opowieścią o adwokacie i o tym, o czym powiedzieć nie może, gdyż oznaczałoby to jego koniec. Trzeba więc iść w stronę końca, umrzeć, zniknąć, zostać zapomnianym, nie-piszącym, otchłanią. Adwokat wie, co go czeka, gdy odpowie na wezwanie/wyzwanie widma. A zarazem nie ma pojęcia. Ma świadomość, że jego podmiotowość się rozpadnie, nie wiedząc, że po śmierci może go czekać życie, które wygnał. W ramach oporu, który nas nawiedził, śmierć, $\mathrm{w}$ tym śmierć akademicka, nie jest tylko pragnieniem wolności (Palmerino, 2011, s. 299), ale wolnością jako taką i śmiercią władzy. 


\section{Mowa milczenia i nie-widzenie}

Podążając majaczącą linią ujścia, która zanurza się w mroku, można powiedzieć, że milczenie Bartleby’ego nie jest w tym kontekście produktem władzy, elementem kultury ciszy. Nie został on uciszony, dlatego że został wytworzony przez dyskurs jako określony podmiot (Foucault, 1998, 2002), ale jest ciszą, która rozbrzmiewa przed dyskursem. Bartleby nie jest kimś, kto został uciszony, a raczej jest niewyrażoną utopią. Jak pokazałem w części pierwszej, władza adwokata sprowadza się nie tyle do odbierania głosu Bartleby'emu, ile do namawiania go do mówienia. Mechanizm mówienie-milczenie ulega zatarciu i okazuje się niezdolny do produkowania wiedzy i utrzymywania panowania. Milczenie Bartleby'ego nie jest wytworem strachu, ale budzi strach. Bartleby ujawnia złudzenie władzy nad językiem.

Nie będąc ofiarą, nawiedzając zarówno studentów, jak i nauczycieli, Bartleby nie jest kimś, komu należy dać głos, włączyć w ramy dozwolonych wypowiedzi. Nie będąc milczeniem wytworzonym przez nauczyciela, nie staje się również mową przez niego powołaną. Cisza, milczenie są oporem, który rozsadza ramy dyskursu, a nie jedynie poszczególne wypowiedzi. Tym samym zarówno strategia nadzorowania dyskursu przez nauczyciela, jak i strategia wysłuchiwania i nawiązywania dialogu okazują się nie tylko przejawem władzy, ale również są nieskuteczne. Bartleby ujawnia język, który opiera się na inkluzji, tłumaczeniu, że każde wyjaśnienie jest wyjaśnieniem, które produkuje sam narrator, i nijak się nie odnosi do „przedmiotu”.

Liberalne, ale też i lewicowe pragnienia dania głosu uczniom, tym, którzy są uciszani, opiera się z perspektywy Bartleby’ego na inkluzji, która stanowi dopasowanie do tego, co jest. Może i ramy zostają lekko rozszerzone, ale sama zasada nie zostaje zanegowana. Możliwe nawet, że strategia związana z "głosem”, „mówieniem” jest strategią kolonizacyjną - domaganie się zabierania głosu i redukowanie do głosu w konfrontacji z opresją może stanowić również system opresji (zob. Hao, 2011; Szwabowski, Wężniejewska, 2017).

Bartleby, nawiedzając przestrzeń, jawi się jako halucynacja, ulokowany w kącie oka adwokata, zarazem widoczny, jak i niewidoczny, ukazuje również złudzenie kontroli nad widzialnością, nad przestrzenią i ciałami. Spojrzenie kopisty często omija wzrok pracodawcy, jak i sama postać majaczy w oczach władzy, aż ostatecznie wymyka się wszelkiemu spojrzeniu, stając się duchem.

Wymykanie się oku i wymykanie się ustom ukazuje, że studiowanie jako inna praktyka edukacyjna nie może dopasować się do istniejących struktur. Nie zamieszkuje ono w murach szkolnych czy uniwersyteckich. Mury te oddzielają od zielonej trawy (zob. Springer, 1965; Marx, 1953). Wskazuje ono ponadto, że pragnienie pracodawcy-nauczyciela jest pragnieniem władzy, dla 
której nie ma miejsca podczas studiowania. Pracodawca-nauczyciel nie tylko doświadcza niemożności pełni władzy, granic swojego panowania i kruchości własnej pozycji, lecz także dodatkowo odcina się od możliwości zbawienia. Dopóki próbuje utrzymać swoją pozycję podmiotową i dominującą relację, dopóty inny świat staje się dla niego niedostępny, jest królestwem szaleństwa.

Edukacyjna szczelina, otwarta przez Bartleby’ego nawiedzającego martwe instytucje, widmo życia skrytego za murami, jest podwójnym wyzwaniem władzy. Doświadczenie granic jest jednocześnie doświadczeniem bezsensu tego, co istnieje, co zostało powołane przez władzę. Ukazując to, otwiera równoczesnie przesmyki w stronę otchłani - utopijną otchłań, punkt wyjścia.

\section{To, co nie-zostaje}

Nawiedzenia przez Bartleby'ego wywołują wiele efektów: tak jak Bartleby jest widmem, tajemniczą wielością, tak też przejawia się na wielu płaszczyznach, przenika zróżnicowane momenty i akty. Rozszczepia się, przenikając instytucje edukacyjne. Pomimo wspomnianej wielości jedynym, co je łączy, jest nawiedzenie. Bartleby wytrąca nas, edukatorów, z pewności (Palmerino, 2011). Jest on posłańcem (Agamben, 2009) - treść przesłania i skąd przybywa nie są do końca jasne. Jest widmem, które daje do myślenia (Derrida, 2016), ale sam Bartelby za bardzo nie daje się pomyśleć.

Opowieść zostaje urwana, adwokat milknie. Jego okrzyk, a potem milczenie mogą sugerować, że lekcja, której udzielił Bartleby, przyniosła skutek - zaprzestał opowieści stanowiącej próbę utrzymania panowania. Milknie, jakby wyzbył się pragnienia panowania. I to jest chyba lekcja, której udziela nam osobliwy kopista.

Pragnienie zarządzania wpisane w edukację (Szwabowski, 2019) wraz z jej kulturą milczenia oraz mówienia, widzialności i niewidzialności (zob. Lewis, 2012) jest pragnieniem $\mathrm{z}$ tego świata, które powinno być odmówione, aby wyjść poza władzę widzenia i mówienia w stronę swobodnego studiowania. Bartleby jest więc śmiercią ustanowionego podmiotu i jego zbawieniem, by stał się widmem.

To optymistyczne zakończenie chciałbym wzmocnić jeszcze jednym stwierdzeniem. Przykład Bartleby’ego pokazuje, że to władza stara się zapanować nad tym, co jej się wymyka, a nie produkuje „opór”. I chociaż znaczenie nam się wymyka, widmo rozszczepia się i zwielokrotnia, a utopia jest nie-widzialna, to (nie)wiemy, jaki mamy wybór.

A Piętaszek tańczy. 


\section{Bibliografia}

Agamben G. (2009). Bartleby, czyli o przypadkowości, tłum. S. Królak, w: H. Melville, Kopista Bartleby. Historia $z$ Wall Street, tłum. A. Szostkiewicz. Sic!, Warszawa.

Agamben G. (2018). Idea prozy, tłum. E. Górniak-Morgan. Fundacja Augusta hrabiego Cieszkowskiego, Warszawa.

Bednarek J. (2012). Polityka poza forma. Wydawnictwo Poznańskie, Poznań.

Bevenrungen A., Dunne S. (2007). "I'd prefer not to". Bartleby and the Excesses of Interpretation. „Culture and Organization”, nr 13 (2).

Biesta G. (2004). Against Learning. Reclaiming a Language for Education in an Age of Learning. „Nordisk Pedagogik”, nr 1.

Biesta G. (2010). Good Education in an Age of Measurement. Paradigm Publisher, Boulder, Colorado.

Burzyńska A. (2013). Dekonstrukcja, polityka i performatyka. Universitas, Kraków.

Bush G. (1990). "I'd Prefer not to": A Research Note on Resistance to Office Work in Some Post World War II American Films. „Labour History”, nr 31 (3).

Canepari-Labib M. (2005). Old Myths - Modern Empires. Power, Language and Identity in J.M. Coetzee's Work. European Academic Publishers, Bern.

Chutorański M., Szwabowski O. (2017). Wszechobecna władza, w: J. Król (red.), Z badań nad tradycja polskiej pedagogiki. T. 4. Władza - edukacja - wiedza. Volumina.pl, Szczecin, s. 193-208.

Coetzee J.M. (2003). Czekając na barbarzyńców, tłum. A. Mysłakowska. Znak, Kraków. Coetzee J.M. (2007). Foe, tłum. M. Konikowska. Znak, Kraków.

D'Hoest F., Lewis T.E. (2015). Exhausting the Fatigue University: In Search of a Biopolitics of Research. „Ethics and Education”, nr 10 (1).

D'Hoest F. (2017). Apprenticeship Under Study: Toward an Educational Dimension of Apprenticeship, w: C.W. Ruitenberg (red.), Reconceptualizing Study in Educational Discourse and Practice. Routledge, London.

Deleuze G. (2004). Foucault, tłum. M. Gusin. DSW, Wrocław.

Deleuze G. (2009). Bartleby albo formuła, tłum. G. Jankowicz, w: H. Melville, Kopista Bartleby. Historia $z$ Wall Street, tłum. A. Szostkiewicz. Sic!, Warszawa.

Deleuze G., Guattari F. (2015). Tysiąc plateau, tłum. zbiorowe. Fundacja Nowej Kultury Bęc Zmiana, Warszawa.

Derrida J. (2016). Widma Marksa, tłum. T. Załuski. Wydawnictwo Naukowe PWN, Warszawa.

Ford D.R. (2016). Teaching, Learning, and Studying in the Baltimore Rebellion. „Policy Futures in Education", nr 14 (2).

Foucault M. (1998). Nadzorować i karać, tłum. T. Komendant. Wydawnictwo Fundacji Aletheia, Warszawa. 
Foucault M. (2002). Porządek dyskursu, tłum. M. Kozłowski. słowo/obraz terytoria, Gdańsk.

Foucault M. (2014). Bezpieczeństwo, terytorium, populacja, tłum. M. Herer. Wydawnictwo Naukowe PWN, Warszawa.

Gatto J.T. (2010). Weapons of Mass Instruction: A Schoolteacher's Journey Through the Dark World of Compulsory Schooling. New Society Publishers, Gabriola Island.

Hao R.N. (2011). Rethinking Critical Pedagogy: Implications on Silence and Silent Bodies. „Text and Prefromance Quaterly”, nr 31 (3), s. 267-284.

John Taylor Gatto's Statement, The Bartleby Project; http://www.bartlebyproject.com/ gatto.html (dostęp: 12.04.2018).

Krips H. (2012). Politics of Overconformity: Bartleby Meets Žižek. „Communication and Critical/Cultural Studies", nr 9 (3).

Kruszelnicki W. (2015). Lifelong learning i poradoznawstwo w perspektywie krytycznej: pedagogie konformizmu i rządomyślności. „Teraźniejszość - Człowiek - Edukacja”, nr 18 (1).

Lewis T.E. (2012). The Aesthetics of Education: Theatre, Curiosity, and Politics in the Work of Jacques Rancière and Paulo Freire. Bloomsbury Publishing, London.

Lewis T.E. (2013). On Study. Giorgio Agamben and Educational Potentiality. Routledge, London.

Lewis T.E. (2014). It's a Profane Life: Giorgio Agamben on the Freedom of Im-potentiality in Education. „Educational Philosophy and Theory”, nr 46 (4).

Lewis T.E. (2017a). Study: An Example of Potentialism, w: C.W. Ruitenberg (red.), Reconceptualizing Study in Educational Discourse and Practice. Routledge, London.

Lewis T.E. (2017b). Beyond Measure. Studying the Educational Logic of Patti Lather's Getting Lost. „Qualitative Inquiry”, nr 23 (4).

Lorenz J. (2005). Escape from the Dead Letter Office. „Interventions: International Journal of Postcolonial Studies", nr 7 (1).

Malewski M. (2010). Od nauczania do uczenia się. O paradygmatycznej zmianie $w$ andragogice. DSW, Wrocław.

Marx L. (1953). Melville's Parable of the Walls. „The Sewanee Review”, nr 61 (4), s. 602-627. McCall D. (1989). The Silence of Bartleby. Ithaca, London.

McLaren P. (2015). Życie w szkołach. Wprowadzenie do pedagogiki krytycznej, tłum. A. Dziemianowicz-Bąk, J. Dzierzgowski, M. Starnawski. DSW, Wrocław.

Melville H. (2009a). Kopista Bartleby. Historia z Wall Street, tłum. A. Szostkiewicz. Sic!, Warszawa.

Melville H. (2009b). Bartleby, The Scrivener: A Story of Wall Street. HarperCollins Publisher, London.

Monahan T.I., Torres R.D. (2010). Schools under Surveillance. Cultures of Control in Public Education. Rutgers University Press, New Brunswick-New Jersey-London. 
Ozimek S. (2011). Kopiując śmierć. Patologiczne przestrzenie biura w Kopiście Bartlebym Hermana Melville’a i Dziwaku Elizy Orzeszkowej. „Wiek XX. Rocznik Towarzystwa Literackiego im. A. Mickiewicza”, 4(46), s. 121-143.

Pacewicz K. (2015). Od biopolityki do biooporu? Deleuze (dez)interpretuje Foucaulta, w: M. Falkowski, K. Pacewicz, C. Zgoła (red.), Foucault: źródła/ujścia. Wydawnictwo Eperons-Ostrogi, Kraków-Warszawa.

Palmerino G. (2011). Teaching Bartleby to Write: Passive Resistance and Technology's Place in the Composition Classroom. „College English”, nr 73 (3), s. 283-302.

Raunig G. (2009). W trybie modulacji fabryki wiedzy, w: K. Chmielewska, K. Szreder, T. Żukowski (red.), Czytanki dla robotników sztuki. Kultura nie dla zysku. Fundacja Nowej Kultury Bęc Zmiana, Warszawa.

Reed N.C. (2004). The Specter of Wall Street: „Bartleby, the Scrivener” and the Language of Commodities. „American Literature”, nr 76 (2).

Ruitenberg C.W. (2017). Introduction: Retrieving and Recognizing Study, w: C.W. Ruitenberg (red.), Reconceptualizing Study in Educational Discourse and Practice. Routledge, London.

Schultz R.T. (2011). White Guys Who Prefer Not To: From Passive Resistance („Bartleby”) to Terrorist Acts (Fight Club). „Journal of Popular Culture”, nr 44 (3).

Simons M., Masschelein J. (2006). The Learning Society and Governmentality: An Introduction. „Educational Philosophy and Theory”, nr 38 (4).

Springer N. (1965). Bartleby and the Terror of Limitation. „PLMA”, nr 80 (4).

Stańczyk P. (2010). Milcząca zgoda, kultura ciszy i polityka głosu. „Teraźniejszość - Człowiek - Edukacja. Kwartalnik Myśli Społeczno-Pedagogicznej”, nr 3 (51), s. 25-38.

Stańczyk P. (2013). Człowiek, wychowanie i praca w kapitalizmie. W stronę krytycznej pedagogiki pracy. Wydawnictwo Uniwersytetu Gdańskiego, Gdańsk.

Starego K. (2016). Uwolnienie podmiotowości przez u-wolnienie czasu szkoły. O komodyfikacji tożsamości, kulturze kompetencji i o pewnej możliwości wyjścia z zatrzasku indywidualizacji. „Parezja”, nr 1 (5).

Swoboda T. (2010). Historie oka. słowo/obraz terytoria, Gdańsk.

Szkudlarek T. (2009). Wiedza i wolność w pedagogice amerykańskiego postmodernizmu. Oficyna Wydawnicza „Impuls”, Kraków.

Szwabowski O. (2015). Agambenowska szczelina edukacyjna. Recenzja Tyson E. Lewis, On Study: Giorgio Agamben and Educational Potentiality, Routledge 2013, „Pedagogika Szkoły Wyższej", nr 1, s. 121-134.

Szwabowski O. (2016). Dynamika „wnętrze/zewnętrze” a "bycie obok” w kontekście nie-edukacji wyższej. „Pedagogika Szkoły Wyższej”, nr 19 (1), s. 23-49.

Szwabowski O. (2017a). Bartleby, łowca dyskursów. O pewnej formie nie-krytyki. „Kultura - Społeczeństwo - Edukacja”, nr 12 (2), s. 329-344. 
Szwabowski O. (2017b). Poza subsumcje, w: M. Chutorański, J. Moroz, O. Szwabowski (red.), Subsumcje edukacji. Katedra, Gdańsk.

Szwabowski O. (2018). Nocne studiowanie z Bartlebym. „Parezja”, nr 1 (9), s. 65-75.

Szwabowski O. (2019). Nekrofilna produkcja akademicka i pieśni partyzantów. Autoetnografia pracy akademickiej i dydaktycznej w czasach zombie-kapitalizmu. Wydawnictwo Instytutu Pedagogiki Uniwersytetu Wrocławskiego, Wrocław.

Szwabowski O., Wężniejewska P. (2017). An (co)autoethnography Story about Going against the Neoliberal Didactic Machine. „Journal for Critical Education Policy Studies", nr 15 (3).

TeachersCount Blog, The Bartleby Project; https://teacherscount.wordpress.com/2010/01/23/ the-bartleby-project/ (dostęp: 14.04.2018).

The Bartleby Project 2010; http://www.bartlebyproject.com/ (dostęp: 12.04.2018).

The Bartleby Project 2010; https://www.youtube.com/watch?v=ev7Y-XbapLc (dostęp: 15.04.2018).

Vanhoutte K.K.P. (2014). Bartleby the Example and Eros the Idea of the Work: Some Considerations on Giorgio Agamben's 'The idea of study'. „Educational Philosophy and Theory", nr 46 (4), s. 393-405.

Wilde O. (2019). Dusza człowieka w socjalizmie, tłum. J. Dehnel. Wydawnictwo Karakter, Kraków. 